\title{
LESSONS ON SOCIAL JUSTICE: A PEDAGOGICAL REFLECTION ON THE EDUCATIONAL MESSAGE OF THE BOXTROLLS
}

\section{Anna Odrowaz-Coates}

Maria Grzegorzewska University

Email: acoates@aps.edu.pl

\section{ABSTRACT}

The author engages critical media education and norm-critical pedagogy to map out possible methods of critical engagement of students during interpretation of the pedagogical facets of The Boxtrolls (film - 2014). The paper discusses rich analytical material that may be explored by employing The Boxtrolls story. The paper considers the application of social theories in an exploration of the film. Freirean critical consciousness may help to expose conflict, power distribution, social stigma and social divisions. Social structures of oppression, politics of exclusion, masses ruled by fear, prejudice, misunderstanding and violence are explored using the theoretical frameworks of M. Foucault, B. Bourdieu, Z. Bauman and R. Braidotti. The moral values depicted in the film are set against excessive consumption, class divisions, selfishness and deficient parental skills; these are analysed as educational tools for all scholastic levels. Evil is punished and values of friendship, trust, cohesion and cooperation (key ingredients of social capital) are victorious. There is also the opportunity for redemption and social rehabilitation, revealing the complexity of humans and their intersectional

\section{UNISA $\cong$}

Education as Change

Volume 20 | Number 2 | 2016 | pp. 67-85

www.educationaschange.co.za

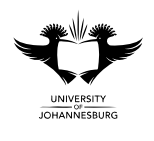

DOI: http://dx.doi.org/10.17159/1947-9417/2016/502 Print ISSN 1682-3206 | Online 1947-9417

(C) 2016 The Author(s) 
positioning. Whilst the human condition and the story are universal, the means of conveying the message reflect technological and societal change.

Keywords: Stereotype; social exclusion; stigmatisation process; disposable bodies; fairy tales in education; power relations; social hierarchy; social norms

\section{INTRODUCTION}

My interest in The Boxtrolls movie emerged spontaneously. My own children (aged 5 and 8 at the time) watched the film and engaged with it at a completely different level to the films they had seen before. One of the most significant demonstrations of the effect the film had on their imaginations was an ongoing urge to find cardboard boxes and either hide in them or cut out holes for arms and legs to pretend they are the Boxtrolls. Many discussions took place between them after seeing the film regarding deeper facets of the story. It aroused my interest into what triggered such a strong reaction and I decided to show the film to their peers from a local governmentfunded school ( 9 children aged 5-10, 4 boys and 5 girls) to observe their reaction to the story, to see what they decide to talk about and observe what they would do in their free play afterwards. Then, after a two week break, I discussed the film with them to see if they remembered it and what they made of it. Being unsure of my own personal bias, a further small group was studied by a primary school teacher in the UK ( 8 children aged 7-10, 4 girls and 4 boys). The teacher was asked to observe the reaction of children and their free play afterwards. She was also asked to discuss the film with children at a later date. Unstructured interviews with Polish and British children took place individually between 10.02.2015 and 31.05.2015.

Further exploration of the film was carried out at the Maria Grzegorzewska University in Warsaw, Poland, in 2015, when over 80 students (31 at bachelor's level and 52 at master's level) took part in a workshop, working with The Boxtrolls. The students, aged 21 and over and in the vast majority female, were aspiring to become educational professionals: teachers, councillors and pedagogues. The story proved to be useful when attempting to encourage critical consciousness amongst students in group workshops and individual assignments.

This paper is based on a small preliminary survey of children's reactions to the film and practical workshops with higher education students and therefore its findings should not be generalised. It is hoped that it may become inspirational material for tutors working with children and adults to employ critical pedagogy in educational practice. The paper concerns interpreting The Boxtrolls through multiple pedagogical lenses and possible (and surely not exhaustive) areas of exploration and interpretation.

The overall aim of this paper is to explore potential methods of engaging students in critical thought on pedagogical and societal issues, using The Boxtrolls as an 
educational tool. The paper opens with a preface dedicated to the world of children and the use of storyline to engage a child's imagination. Subsequently, there are four lessons that illustrate several areas of pedagogical interest. The first is dedicated to the use of characters in the story, whilst the second includes a depiction of a social structure and power distribution. The third contains a discussion on shared values and norms with a critical angle and the final lesson highlights potential areas for critical analysis such as the discourse of whiteness, stereotyping and scapegoating, the creation and maintenance of social divisions and social exclusion, 'figuration', the process of 'trolling' and the ever-present power distribution, analysed in the context of Marxist class struggle, Bourdieuan habitus and norm critical pedagogy. The paper closes with conclusions that The Boxtrolls is potentially packed with educational material, which may be useful in enhancing critical thinking throughout the development of multiple fields of interpretation.

\section{A STORY IN ANIMATION AND THE CHILDREN'S WORLD}

Bruno Bettleheim, an Austrian-American psychiatrist, is, alongside Jean Piaget $\left(1955^{1}\right)$, one of the key contributors to the concept of a children's world, as created by a child's imagination and specific to childhood (1959, 1969, 1976, 1996). Despite wide criticism of Bettelheim's work (cf. Heisig 1977; Zipes 1979; Szajnberg 1992; Sutton 1995) his concept opened an important period in thinking about children and child-oriented research, based on the politically motivated turn in child emancipation of the late 1960s. The child became understood as a creator of specific childhood realities, based on creative imagination and on the alternative reality of fairy tales, perceived as a form of the child's own creation. Concurrent with Bettelheim's discoveries, technical advancements have enabled a gradual shift from written or spoken stories for children, towards the world of animation, where images give a readymade framework of the fantasy world. This empowers the author to guide children in the preferred direction. The US animation industry is particularly successful in combining child psychology with animated stories. The world of animation offers opportunities to engage with children's imaginations and is now widely used as a tool to reach out to children with messages conveying western cultural values and the transmission of educational materials.

If we look at this phenomenon through the lens of critical pedagogy, could we say that this is a form of symbolic violence that puts clear boundaries on the appearance of characters and places shown in the stories? Is it a new form of indoctrination of our children? A. Wasilewska $(2012,9)$ argues that the images on their own are not sufficient to be a tool of symbolic oppression. They exist in a certain habitus, in a certain social context, relevant to children's lives and the level of relevance may affect the amalgamation of symbolic communication. Animated stories for children allow a child to absorb certain psychological, sociological and aesthetic values 
(Handford \& Karolak 2007, 9). They support a certain vision of habitus and the story may have many other positive functions. The storyline method of engagement with a child's imagination involves tying emotions of participants with the intended educational message (Smith \& Vallerga 2006). The story shown on the screen, similar to a story read from a book, often aims to teach a child a moral lesson (Sułek, Król \& Krupiński 2003). Although the story is fictional it may appear realistic and become a mirror of repetitive feelings and emotions present in our culture, showing children how to deal with them. It can become an allegory of catharsis born of the need to free accumulated emotions (Handford \& Karolak 2007, 8).

Catharsis has been present in written human history at least since Aristotle, who in 'Poetics' noted the cathartic influence of listening to music or watching a Greek tragedy (cf. Aristotle 2001, 1131; 1458). In his view these artistic experiences have an overall healing effect on spectators, due to the emotional release they encountered when fully engaged with the art. The Greek word catharsis refers to 'cleansing' or 'purification', brought on by an emotionally charged, strong cognitive experience that may lead to a positive change (cf. Moreno 1946). Scheff (2001) indicates that there needs to be some 'distancing' between somatic discharge and cognitive awareness, which is possible to obtain when a person experiencing catharsis stays in control by being the observer and not a participant. Schultz and Schultz $(2004,506)$ define catharsis as 'the process of reducing or eliminating a complex by recalling it to conscious awareness and allowing it to be expressed'. ${ }^{2}$

Stories can enhance children's empathy, let them see the world from the point of view of another and take account of another person's needs (Goleman 1997). Stories for children can also have a therapeutic effect, by dealing with trauma, fears and worries (Molicka 2002; Brett 2005; Handford \& Karolak 2007). The intensity and density of the emotional atmosphere created by the story may evoke fear, worry, compassion, sadness, pain, grief, joy, excitement or relief and this aids the child's engagement with the story (Molicka 2002, 142). The reality created by the story is coherent with the child's way of thinking, which allows the child to decentralise and overcome egocentric attitudes (Molicka 2002, 143). The dramatic effect of events presented in a story may influence children so deeply that they become immersed in these events. They may feel like they are there, inside the story (Molicka 2002, 144).

When analysing The Boxtrolls some of the 80 Polish students, mentioned in the introduction, felt that the film may be somewhat unsettling for younger children. However, Bettelheim discovers that children receive only content that they are able to accept and that corresponds with their level of maturity. The symbols presented in the story let them refer to their own lives, help them understand their own problems and allow them to experience a form of cathartic relief (Molicka 2002, 148-149). According to Molicka $(2002,144)$ one may learn that the source of children's fantasies is the actual reality that surrounds them and that stories like The Boxtrolls may have an impact on children's development as well as entertain and perform a 
therapeutic function (cf. Brun et al. 1993; Borecka 2004; Handford \& Karolak 2007; Kozłowska 2007; Molicka 1999, 2002, 2003). Whilst adults may be able to enter the symbolic level of the story, children are believed to perceive the world more directly and intuitively (Brun et al. 1993, 58-59). J. Nielsen (1986) is amongst those who wrote about symbolic ways in which to experience the world (Brun et al. 1993, 26), whilst B. Holbeck (1987) writes that the symbolic elements of fairy tales provide the emotional colour of characters, events and phenomena of the real world (Brun et al. 1993, 24). Stories like The Boxtrolls have some potential to shape moral attitudes, form personality, enhance imagination, help to understand other people and their motives and finally to allow one to emphasise and distinguish good from evil (cf. Jaszczyk \& Kochaniak 2006, 15).

\section{LESSON 1 - CHARACTERS}

The fairy tale metaphors used in the socialisation of children resemble interdependencies applicable in a given social system (cf. Le Goff 1997). A story may smuggle in cultural truths about injustice and harm, it may reveal and condemn the worst human instincts (cf. Graczyk \& Graban-Pomirska 2002, 275-277), but it may also preserve societal order, based on the reproduction of conformist behaviours and stereotypical role models. The story shows an authoritarian and negligent parental style (Ponzetti 2003), with a lack of intergenerational dialogue, a lack of communication and a lack of interest in the child. These negative behaviours are eventually transformed through the life-changing experience of the characters. The 'role models' of The Boxtrolls can be placed amongst the archetypal characters of cultural transmission (Wasilewska 2012, 8). According to Jung (1956), archetypes are subconscious primeval role models or patterns of behaviour, common to humankind that appeal to people through the use of metaphors and symbols (cf. Brun et al. 1993, 19-20). In this case examples of the negative archetypes are a passive, self-focused mother (a Victorian stereotype of upper-class motherhood) and the villain. Being aware that Carl Jung's archetypes theories $(1921,1947,1948,1956)$ are not universal and came under considerable scrutiny (cf. Shelburne 1988; McGowen 1994; Holt 2010) it is possible to include them within academic discussion, for instance widening students' knowledge of the feminist approach to Jung's theory (Reed 2009).

In fairy tales, characters, artefacts and actions are supposed to cause a certain emotional reaction amongst the recipients of the story. In The Boxtrolls, it is intended that one may feel sadness for the girl, who lives in a wealthy household, but often feels unwanted and lonely. Archibald Snatcher causes fear and confusion. His Machiavellian manipulations of public opinion and of his subordinates demonstrate his evil nature. His split personality and the taking on of a transgender role covers up his perceived ugliness and allows him to convince the crowd to believe the manipulative story about the mythical 'others' (creatures known as Boxtrolls). By 
taking on two roles, he gives himself credibility amongst the local community, but he loses credibility in the eyes of the preferred viewer, who subconsciously desires his defeat in his quest to undermine the Boxtrolls. His subordinates follow him blindly, which may show children how weak people can be, especially when confronted with oppressive authority and how easily they may be manipulated into making morally wrong choices. The characters fall into D. Haraway's view on 'figures' who are never innocent (cf. Smelik \& Lykke 2008, 38). They make an impact. They can be viewed as transmitters of ideological positions and used as models potentially useful in attempts to expose and explain the mechanisms of colonialism, racism, social norms and the use of violence. The Boxtrolls are depicted as Z. Bauman's 'wasted humans' $(2004,5)$. The story shows that they can be saved, but only through selfempowerment.

According to M. Lundgren and L. Norrby (1988), positive characters in a story may symbolise the features that children love in their parents, whilst frightening creatures may likewise symbolise the features that a child is afraid of and that they dislike in their parents. The eradication of these negative archetypes in fairy tales leads to a feeling of relief without any associated guilt (Brun et al. 1993, 59), so it has a positive and cathartic effect. It helps children defuse their confusing emotions towards significant others. Crying, for instance, is involuntary and rather instinctive, yet it has a cathartic effect (cf. Breuer \& Freud 1974).

Perhaps a more subliminal message is directed at adults, one which exposes apathy and a lack of civic action. One may be forced to consider if we are all made to think and act within a box provided by our culture and by our social conditioning. It is highlighted in the closing musical piece composed by M. Reynolds in 1962 in protest against conformist middle-class attitudes, uniformity of choice, appearance, actions and thinking (performed by Loch Lomond 2014).

\section{LESSON 2 - POWER DISTRIBUTION}

Knowledge, subjectivity and socially produced 'types of normativity', fixed in a particular culture at a particular time frame, affect individual experiences (cf. Foucault 1992, intro). According to Foucault there is no universal truth and all knowledge is socially produced, therefore there is no pure, real knowledge, only different truths. The concept of 'false consciousness', that Michel Foucault rejects, may become an interesting approach when searching for interrelations between knowledge and power in the context of The Boxtrolls. Within the Marxist approach to knowledge that serves the dominant power, one may think about the potential of 'false knowledge' emerging in the context of the situation the Boxtrolls find themselves in - and question who is the greatest beneficiary of power? There are other potential angles to the exploitation of knowledge, such as using it for illegitimate goals. In this case the evil mastermind forces an inventor to construct a machine, putting the inventor's technical knowledge to malevolent use. 
Power transcends politics and is demonstrated in the socialised and embodied practices of everyday life, whilst knowledge operates within externally bestowed regimes of truth, influencing what we learn and how. Power is overwhelmingly present everywhere, diffused and embodied in discourse, knowledge and 'regimes of truth' (cf. Rabinow 1991). To challenge power is not a matter of seeking some 'absolute truth' (which is in any case a socially produced power), but 'of detaching the power of truth from the forms of hegemony, social, economic, and cultural, within which it operates at the present time' (Rabinow 1991, 75).

Knowledge, perceived through a Freirean critical consciousness lens, is a limited, externally bestowed social property that can perpetuate false 'reality'. It resembles a closed, endemic way of socialising children and a narrow channeling of a uniformed world's vision, which forms opinions of people who have no access to alternative sources of information and who are captured in this 'false reality'. When based on no evidence or evidence manufactured to support a certain ideology, it can be a tool of great social manipulation (cf. McLaren 1989; Giroux 1981). In this case, people are led to believe that the Boxtrolls are dangerous, evil creatures who eat babies and have no value in society. This idea of Boxtrolls, based on false knowledge, creates a clear demarcation line between the elites and them - the 'ethnic' others or even 'other species', whose language and customs we do not know and who look different to us and live in a sewer (associated with waste, dirt, darkness). In the film, the dominant public discourse surrounding the Boxtrolls reinforces the unjust distribution of power. The discourse in Foucault's conceptualising can be described as materialised practice and a certain 'way of speaking' (Foucault 1972, 193). The discourse is related to habitus that equips individuals with certain language and symbolic capital. One of Foucault's takes on discourse from his 'On ways of writing history' (1967) is as follows: 'there is nothing to be gained from describing this autonomous layer of discourses unless one can relate it to other layers, practices, institutions, social relations, political relations, and so on' (O'Farrell 2005, 80).

The idea of creating a certain image of undesired figures flows into 'figuration' forming a uniformed image of these figures in the collective mind. The stigmatisation of the Boxtrolls, by creating myths about their habits and making a clear distinction between them and 'the rest of the public' increases personal distance towards them from the town's citizens. This makes the victimisation and stigmatisation of the group easier. However, such exclusion and spatial separation is not enough to maintain social order. The conflict in the film escalates and the dominating group looks for justification to dispose of these 'disposable bodies' (Braidotti 2013, 117) who, in the public collective mind of Cheeseville, do not contribute to society and pose a significant threat to public safety and stability. There is civic approval for extermination of the Boxtrolls and Archibald Snatcher satisfies his thirst for power by fuelling public fear. The Boxtrolls become, using Z. Bauman's rhetoric, disposable lives or wasted people, for whom there is no place in society and the 
social order (2004). The violence caused by the myths surrounding the Boxtrolls, intentionally built to dehumanise them and highlight their otherness, fuels the mechanisms of fear and conformity amongst local citizens. The politics of exclusion is also evident in the abuse of power by the social elite, who ignore the public interest and instead choose to buy gourmet cheese for an exclusive party, rather than fund the building of a children's hospital. The social divisions and stratification system are maintained by significant differences in the habitus and doxa of the leader (Lord Portley-Rind) and the average citizen. The insignias of power, demonstrated by the white hat together with the exclusive eating habits, show power as an element of Bourdieuian reproduction of social systems and the maintenance of social divisions, via a justification of class differences resembled in their habitus.

\section{LESSON 3 - VALUES}

Culture as seen by Foucault is 'a hierarchical organization of values, accessible to everybody, but at the same time the occasion of a mechanism of selection and exclusion' (Foucault 2001, 173). In The Boxtrolls, universal values of goodness, sensitivity to the plight of humans and animals, solidarity and truthfulness, are affirmed and the issues of social injustice are exposed. The evil man is defeated and importantly he receives a chance for redemption, but declines it and this leads to his self-destruction. Moreover, The Boxtrolls overcomes the stereotypical duality of fairy tale worlds, where everything comes in two opposites. Traditionally good equals beautiful and the world is divided into rich and poor, pretty and ugly. The Boxtrolls film gives children a much more complex intersectional take on life, reflecting the reality of normal existence. It puts strong emphasis on the message that appearances or possessions are not the most important factors and that being at peace with oneself, thinking about others and being good on the inside are of the highest value.

In traditional fairy tales, ethical values are emphasised by harsh punishment of the unethical characters and reward for the righteous characters. Reward and penalty are in equilibrium but they are often disproportionate to the actions. Evil is always punished and there is no compassion for the perpetrator or mercy and redemption (Molicka 2002, 141). The Boxtrolls offers a broader approach, allowing the helpers of the evil mastermind to change and be forgiven. Moreover, the main character, Eggs, who is one of the victims of Archibald Snatcher's wrongdoings, shows a degree of empathy towards his perpetrator and (without success) attempts to help him change the way he thinks about the world and most of all, about himself. Snatcher thinks that gaining certain privileges and participating in certain ceremonies are the only ways he can feel complete and can express his true self. This desire is deemed to be false, as he fails to follow the moral lesson: he can not change who he is by appropriating symbols of higher status - he can only change through his own actions. 
The story shows complicated relationships between different characters and different social strata: internal conflicts, manipulation and deception, such as the interactions between the trolls and the little boy, between the boy and a girl from a different class and between the girl and her family. The family is initially shown as lacking in sound judgement, trust, parental skills and interest in the child. It does not listen to the child's problems and anxieties, but regains a strong family bond in the end. Social cohesion, family, trust and love are depicted as primary values by being the triumphant ones at the end. The scrutiny of shared values to reveal mechanisms of social injustice is of paramount importance to prevent 'scapegoating' of the weak, poor or politically undesirable.

\section{LESSON 4 - CRITICAL DISCOURSE (ADULT PERSPECTIVE)}

As simplistic as it may sound, clear and basic resolutions to social divisions and conflicts, which don't reveal the full complexity of societies, appeal to children's imagination. Unsophisticated distinctions between good and evil that perpetuate the myth that 'evil' is usually located in a person and that the evil will finally be destroyed, seems to follow the Christian logic of sin, repentance, forgiveness and redemption. The film is however a western production, which comes with a certain worldview. Despite these limitations or even because of them, the film may be recommended as an educational tool for adults. Whilst children watching the story empathise with the unjustly subjugated Boxtrolls and sympathise with the endangered group, they unconsciously experience the educating effect of Freirean pedagogy of the oppressed (1970) and fulfil Freire's intention to 'read the world'. They see the injustice and feel it should be addressed. It would be interesting to examine if such feelings are universal and shared by children across the globe regardless of their social or ethnic background. This is because the understanding of childhood and the shared social values vary amongst cultures and different socio-political settings. Moreover, there are a significant number of research cases that prove that within a single society, children may display diverse abilities and interests (Matsumoto \& Juang 2007). Concurrently, in spite of what was argued in the opening paragraphs, in her early work, Margaret Mead (1932) undermined Jean Piaget's theory about the universality of the animistic stadium of a child's development and Lawrence and Kohlberg's theory pertaining to stages of moral development (Matsumoto \& Juang 2007). These facts suggest that one should not make assumptions about how the story might be received in different cultural or religious contexts. Nevertheless, for this particular paper an observation of the reaction of children aged 5-10 to the film in Poland and the United Kingdom (a small snowball sample: 9 children in Poland and 8 in the UK, involving observations and unstructured interviews), has allowed the drawing of some preliminary conclusions, which suggest that the story is beneficial 
to these children's understanding of social injustice. As mentioned before, children's imagination engages with the simple and direct communication transmitted by the story. Through further discussion one can increase a child's reflexivity, by posing additional questions about the more complex issues present in the story. However, the intersectional, multilevel picture may be more apparent to adults, due to their higher levels of reflexivity and previous life experience (Dewey 1933). Although it may be disputed, it is considered to be proven by King and Kitchener (1994) that people can be positioned on a seven point scale of being able to make a reflexive judgement. Having a higher degree of reflexivity allows one to have a more critical approach to life in general and therefore to The Boxtrolls film as well. It may be of benefit to tutors to engage their students in an analysis of The Boxtrolls through a critical lens to enhance their level of reflexivity. This practice was successfully used during lectures dedicated to a multitude of social issues, with bachelor's and master's degree students at the Maria Grzegorzewska University in Warsaw, Poland (2015, approximately 80 students). The most apparent, yet not exclusive, areas for classroom discussions and written assignments may be: the discourse of whiteness, post-colonial studies, stereotypes, role models, the process of trolling, social structure, areas of social exclusion and finally, human and children's rights.

In this film, the discourse of whiteness (Frankenberg 1997; Keating 1995; Mahoney 1997) might be observed when looking at the ethnicity of the social elites in the town, who form a cheese tasting society. The members of this society, who are also decision makers, are exclusively male and middle to upper class. They consider themselves to be superior to the other town citizens and are distanced from reality and corrupt in thinking only about themselves and their selection of the most expensive cheeses. In fact, the majority of town citizens are white, which gives an open field to deconstruct the setting through a post-colonial framework (Bhabha 2010), decentralised from the western, ethnocentric bias (Said 1978; Gandhi 2008).

Remaining within critical discourse, one may question the role models shown in the film. It can be argued that the two main child characters can be considered positive role models. Only one of them lives in a 'traditional' family model. However, as already mentioned, the relations in her family are far from ideal and some may argue that the girl is constructed far too stereotypically. The 'evil' characters do not have children or at least there is no mention of them, which is a common TV construction when depicting villains as people with no family. Along with their negative actions, this hinders the viewer from sympathising with them. Portraying them as having no family bonds makes them less human and helps children in the audience to disassociate the negative characters from the other 'kind' people. This further justifies and gains approval for the removal of stigmatised individuals from society or even their death.

Social science research uses 'figuration' to illustrate theories and reveal certain structures of how subjects are socially constructed (cf. Norbert Elias 1978 or 
Raymond Morrow 2009). Social figures interwoven into social structures are also explored as knowledge-producers in their own right. This opens the dilemma of popular forms of figuration. In the stigmatisation or celebration of certain figures, one may apply historical discourses of gender, ability, race, religion, sexuality, age, class and ethnicity to reflect on structures of social and political life.

By analysing this film through a pedagogical lens, one may extract ideas on how the structures of contemporary forms of racism, heterosexism, coloniality and bio-political powers are reconstructed by the figures portrayed in the story and how justice is done to the positive figures in the film, who emerge from violent histories. Furthermore, it may be questioned what role emotion has in the prioritisation or vilification of characters in the film and beyond. Looking at the multidimensional message of the film, one may ask why the producers chose to vilify certain characters. Which gender, ethnicity, class, sexual identity and orientation are they and what body were they given? One may argue that a very traditional way of depicting the 'evil mastermind' was used. Simultaneously, it is quite noticeable how the characters depicted in the film are constructed to ostracise and vilify certain groups. For example, in the film a popular street theatre play shows a story of trolls that eat children and are to be feared. This practice of attempting to influence public opinion through popular media may be considered to be a process of 'trolling', i.e. attempting to turn a certain individual, or a group, into a troll. In modern social science the process of trolling often refers to trolling online (Lumsden \& Morgan 2012; Graham \& Mathis 2012). However, 'trolling' in this case is understood as depicting a person or a group in a negative light to manipulate public opinion and to intimidate the persons subjected to 'trolling'. The concept of trolling has been used by feminist thinkers such as Mantilla (2015). Looking for examples in modern society, one may focus on the deconstruction of the internet trolling of noticeable women; for example: Mary Beard, Stella Creasy, Caroline Criado-Perez or Emma Watson, who were trolled in social media to silence them and undermine their authority and self-worth. ${ }^{3}$ The process of trolling may have an impact on other disadvantaged groups, who are socially 'trolled' to be silenced.

The possibility exists that such groups, if weakened through a lack of voice, may face a terrible fate, including extermination. The post-humanist outlook of Rosi Braidotti (2014) towards disposable bodies, or Zygmunt Bauman's 'wasted humans' (2004) may be pertinent. In The Boxtrolls, the trolls themselves are such a group that is defenceless and sacrificed. A transhumanist thought (Haraway 2006) may also be applicable as the trolls are not quite human, but are some other species. Initially, the people of Cheeseboard do not realise how interdependent they and the Boxtrolls are, as the Boxtrolls turn out to serve society in many useful roles, including through modern concepts such as recycling. The Boxtrolls also depend on wider society and its consumerism, which creates the waste they utilise. The post-human concept is also present when set against human inventions that may lead humanity to its 
eventual end. For example, the kidnapped inventor, placed under pressure, constructs a machine of destruction. Moreover, the Boxtrolls who are captured are also forced to work on the invention built to kill them. It may be a good analogy of Fascism and other 'isms' that are known to have used intimidation to co-opt victims into cooperators.

During lectures with university students, to enhance critical thinking on social mechanisms and psychological conditioning of individuals, it may be advantageous to talk about the value of life and how people instinctively cling to it at all cost. Excessive consumption (in the case of Cheeseboard, of gourmet cheese) infringes on the morale and sustainability of the town's citizens. This is a familiar scenario that is consistent with the exploitation of our planet and of its people. Humans become trapped in their life of comfort and commodities, and do not think or care about the associated long-term costs. This trap is also highlighted by the film, which attempts to express an extensive criticism of existing education systems that aim to mould pupils into certain types of 'future workers'. 'We are all in boxes', we become boxed within a certain context of culture, history and beliefs, educational grounding and so on.

When talking to students with a pedagogical background, it may be worth drawing their attention to the street theatre performance that takes place at the end of the film. The town citizens enjoy reliving the moments of change, when the Boxtrolls are saved and their headsman dies. It is the same as typical commemoration days, where important events are remembered and often reconstructed. Such practices fall within the memory boom of the 1970s (which occurred when WWII survivors started to share their stories with the wider public (Boyer \& Wertsch 2009) and depict what a reflexive biography is and how it may be re-worked. New societal structures emerge allowing people to coexist with the Boxtrolls in peace and harmony again. It is hardly a revolution though, as the ruling elites maintain their high status through embracing the idea of getting closer to people they are meant to 'serve' by using public events. So the system is reproduced and the Boxtrolls still appear to be quite low in the societal structure, as they still recycle, fix broken things and represent low-paid labour, but at least now they are accepted and not endangered. Therefore, one may question the extent to which the film perpetuates the idea of a capitalist order, tainted by extensive class divisions, impossible to overcome. The power relations revealed throughout the story can be addressed by applying a multitude of social theories, for example by G. Simmel (1950, 1972), C. Levi-Straus (1966, 1969), M. Mauss (1922), M. Weber (1953), E. Durkheim (1923), J. Derrida (2001) or P. Di Maggio and Ostrower (1992). The film can also become a case for the application of norm critical pedagogy (Odrowaz-Coates 2015) in its approach to social structure, family structure, interactions and the situations shown. University students' feedback on using this children's story to analyse complex social theories has so far been very positive. ${ }^{4}$ It is also possible to encourage students to try a 
multitude of perspectives. For example, look at the perception of some individuals, groups or situations through the eyes of an outside observer from the UN, looking at human rights, minority rights, women's rights, children's rights and issues of safety. Other perspectives for adult students may be those of the oppressed, of a child, of an adult, of a foreign investor, a priest of a chosen denomination and so on. Human rights issues may also be discussed when considering such important matters as fair trials, frontier justice or death sentences. The film has significant potential to be used in educational practice.

\section{CONCLUSIONS}

The Boxtrolls (2014) exposes social injustice and at multiple levels conveys an educational message directed not only at children but also at adults. Looking at the story from the combined perspective of constructivism (Piaget, Vygotsky), symbolic interactionism (Dewey, Mead) and critical theory (Freire, Foucault, Giroux, McLaren) I argue that the story exposes mechanisms of how categories of 'otherness' are socially created and how that leads to social exclusion, myth building, labelling and the maintenance of group stereotypes that may even justify the ruthless extermination of 'unpopular' or stigmatised others. We have many examples in our recent history of such political discourse that encourages genocide and ethnic cleansing. The film addresses universal human conditioning: G. Le Bon's (1985) crowd mentality and social stratification based on Bourdieuian habitus. It includes weaknesses of character such as greed, selfishness, badly placed aspirations and value hierarchies or difficulty in self-acceptance. The Boxtrolls film reflects societal evils, such as excessive consumption without concern for or consideration of the weak and the poor. Simultaneously, the film affirms values of friendship, trust, bravery, empathy, collectivism and activism. It presents a narrative that endorses the idea that appearances or possessions are not the most important elements for happiness and wellbeing. From the point of view of norm critical pedagogy (Bromseth \& Sorensdotter 2014), the societal norms shown in the film depict how some norms serve to justify and maintain power, benefiting certain individuals, groups and social strata. Socially produced norms may therefore reflect and perpetuate injustice in the societal order. The film can be a tool of engagement with university students, when introducing them to various social theories, or just to increase their critical capacity and their level of reflexivity.

\section{NOTES}

1. Although Piaget's theory of the developmental stages of children came under wide criticism, he remains one of the most influential thinkers on education and child development (Lefrancois 2006). Mary Donaldson in her book Children's Mind (1978) 
is very critical of Piaget's claims of childhood egocentrism. She demonstrates that the difference in egocentrism comes not from the child immanently, but from the difference between embedded and disembedded thinking. The disembeddedness narrows children's perspectives, giving a false impression of them, one in which they are unable to consider anything but their own point of view. Gray (1994) and Weiten (1992) question the need for and the relevance of his developmental stages theory. Wood (2008) shows that he underestimates the potential and abilities of very young children. Others (Segall et al. 1990; Vygotsky 1978; Edwards et al. 2000) note that he did not consider the influence of formal western schooling on children's development and therefore ignored the cultural context of developmental stages. His critics also claim that Piaget's works lack operationalisation and definitions of terminology used (cf. Carlson and Buskist 1997; Edwards et al. 2000).

2. The use of catharsis in the field of psychology has been recorded in primal therapy (cf. Janov 2007), emotion-focused therapy (cf. Greenberg 2002; Greenberg et al. 2008) and psychodrama (cf. Kipper 1997).

3. The process of trolling of visible and driven women is a deeply entrenched misogynistic idea of silencing women. The process of silencing women is not new; it has been on-going for centuries. In the middle ages, women were silenced by various methods, one of which was the scold's bridle - a cast iron cage fitted over a woman's head and which included a metal plate with spikes that was inserted into the mouth. The intention was not only to silence that particular woman but also to discipline other women. The trolling of women may therefore be a modern equivalent of the scold's bridle. For a better understanding of what trolling may be, it is sufficient to review some of the caricature pictures of women rights activists from the beginning of the 20th century where conservative propaganda had their images trolled (T. Oneil. 12 Cruel anti-suffragette cartoons. The week. Retrieved from: http://theweek.com/articles/461455/12-cruel-antisuffragette-cartoons (accessed 19 September 2015).

4. This practice has been used successfully during lectures and as a workshop practice when working with small groups of 5-30 students, at Maria Grzegorzewska University in Warsaw, Poland, 01.03.2015-01.05.2015.

\section{REFERENCES}

Aristotle. 2001. The basic works of Aristotle. Edited by R. McKeon. New York: Modern Library.

Baluch, A. 1987. Dziecko i świat przedstawiony, czyli tajemnice dziecięcej lektury. Warszawa: Instytut Wydawniczy Nasza Księgarnia.

Baluch, A. 2005. Książa jest światem. O literaturze dla dzieci małych oraz dla dzieci starszych i nastolatków. Kraków: Universitas.

Baniecka, E. 2002. Bezdomność - przygarnięcie - odnalezienie własnej drogi. Baśń o Kopciuszku braci Grimm w psychologicznej interpretacji Eugena Drewmanna. In Siostry $i$ ich Kopciuszek. Edited by E. Graczyk and M. Graban-Pomirska. Gdynia: Uraeus.

Bauman, Z. 2004. Wasted lives. Modernity and its outcasts. Cambridge: Polity. 
Bhabha, H.K. 2010. The location of culture. New York: Routledge.

Berger, P.L. and T. Luckmann. 2010. Społeczne tworzenie rzeczywistości. Traktat z socjologii wiedzy. Warszawa: PWN.

Bettelheim, B. 1959. Joey: A ‘mechanical boy'. Scientific American 200: 117-126.

Bettelheim, B. 1969. The children of the dream. London \& New York: Macmillan.

Bettelheim, B. 1976. The uses of enchantment: The meaning and importance of fairy tales. New York: Knopf.

Bettelheim, B. 1996. Cudowne i pożyteczne. O znaczeniach i wartościach baśni. Warszawa: WAB.

Borecka, I. 2004. Z motylem w tle. O baśni w biblioterapii i terapii pedagogicznej. Wałbrzych: Wydawnictwo Państwowej Wyższej Szkoły w Wałbrzychu.

Bourdieu, P. 1977. Cultural reproduction and social reproduction. In Power and ideology in education. Edited by J. Karabel and A.H. Halsey, 487-511. New York: Oxford University Press.

Boyer, P. and J.V. Wertsch. 2009. Memory in mind and culture. Cambridge: Cambridge University Press.

Braidotti, R. 2013. The posthuman. Cambridge: Polity Press.

Brett, D. 2005. Bajki które leczą. Gdańsk: Gdańskie Wydawnictwo Psychologiczne.

Breuer, J. and S. Freud. 1974. Studies on hysteria. Harmondsworth: Penguin Books.

Bromseth, B.J. and R. Sorensdotter. 2014. Norm-critical pedagogy. In Gender studies education and pedagogy. Edited by A. Lundberg and A. Werner, 24-32. Gothenburg: Swedish Secretariat for Gender Research.

Brun, B., E.W. Pedersen and M. Runberg. 1993. Symbols of the soul: Therapy and guidance through fairy tales. London: Jessica Kingsley Publishers.

Carlson, N. and W. Buskist. 1997. Psychology: The science of behaviour. 5th edition. Boston: Allyn and Bacon.

Derrida, J. 2001. Writing and difference. New York: Routledge.

Dewey, J. 1933. How we think: A restatement of the relation of reflective thinking to the educative process. Boston: DC Heath and Company.

Di Maggio, P. and F. Ostrower. 1992. Race, ethnicity, and participation in the arts: Patterns of participation by Hispanics, whites, and African-Americans in selected activities from the 1982 and 1985 surveys of public participation in the arts. Washington: Seven Locks Press.

Durkheim, E. 1923. Education et sociologie. Paris: Les Presses universitaires de France.

Edwards, L., J. Hopgood, K. Rosenberg and K. Rush. 2000. Mental development and education. Retrieved from: http://ehlt.flinders.edu.au/education/DLiT/2000/Piaget/begin.htm (accessed 17 February 2016).

Eichelberger, W. and A. Suchowierska. 2008. Bajka to życie albo z jakiej jesteś bajki. Warszawa: Agencja Wydawnicza Jacek Santorski \& Co.

Elias, N. 1978. What is sociology? New York: Columbia University Press.

Frankenberg, R. 1997. Displacing whiteness. Durham: Duke University Press.

Freire, P. 1970. Pedagogy of the oppressed. New York: Herder and Herder. 
Foucault, M. 1972 (1969). The archaeology of knowledge. Translated by A.M.S. Smith. London: Tavistock.

Foucault, M. 1992 (1984). The use of pleasure. The history of sexuality. Volume 2. Translated by R. Hurley. Harmondsworth: Penguin.

Foucault, M. 1995. Discipline and punish: The birth of the prison. New York: Vintage Books.

Foucault, M. 1998. The history of sexuality: The will to knowledge. London: Penguin.

Foucault M. 2001. L'hermeneutique du sujet. Cours au Collège de France, 1981-1982. Paris: Gallimard Seuil.

Gandhi, L. 2008. Teoria postkolonialna [Postcolonial theory]. Poznan: Wydawnictwo Poznanskie.

Giroux, H. 1981. Ideology, culture and the process of schooling. Philadelphia: Temple University Press.

Goleman, D. 1997. Inteligencja emocjonalna. Poznań: Media Rodzina of Poznań.

Graban-Pomirska, M. 2003. Mała dziewczynka we współczesnej baśni literackiej. In $W$ poszukiwaniu małej dziewczynki. Edited by I. Kowalczyk and E. Zierkiewicz. Poznań: Wydawnictwo Konsola.

Graham, C. and K. Mathis. 2012. Frape, stalking and whores: Semantics and social narrative on Facebook. Retrieved from: http://www.interdisciplinary.net/critical-issues/wp-content/ uploads/2012/10/grahamtmpaper.pdf (accessed 17 September 2015).

Graczyk, E. and M. Graban-Pomirska. 2002. Siostry i ich Kopciuszek. Gdynia: Uraeus.

Gray, J.A. 1994. Framework for a taxonomy of psychiatric disorder. In Emotions: Essays on emotion theory. Edited by S.H.M. van Goozen and N.E. Van de Poll, 29-59. Mahwah, NJ: Lawrence Erlbaum Associates.

Greenberg, L.S. 2002. Emotion-focused therapy. Washington, DC: American Psychological Association.

Greenberg, L.J., S.H. Warwar, W.M. Malcolm. 2008. Differential effects of emotion-focused therapy and psychoeducation in facilitating forgiveness and letting go of emotional injuries. Journal of Counselling Psychology 55(2): 185-196.

Hallman, R.J. 1969. The archetypes in Peter Pan. Journal of Analytical Psychology 14: 65-73.

Handford, O. and W. Karolak. 2007. Bajka w twórczym rozwoju i arteterapii. Łódź: Wyższa Szkoła Humanistyczno-Ekonomiczna.

Haraway, D. 1985. A manifesto for cyborgs: Science, technology, and socialist feminism in the 1980s. Socialist Review 5(2): 65-107.

Haraway, D. 1988. Situated knowledges: The science question in feminism and the privilege of partial perspectives. Feminist Studies 14(3): 575-599.

Haraway, D. 1990. Simians, cyborgs and women: The reinvention of nature. London: Free Association Press.

Haraway, D. 2006. When we have never been human, what is to be done? Theory, Culture \& Society 23(7-8): 135-58.

Heisig, J.W. 1977. Bruno Bettelheim and the fairy tales. Children's Literature 6(1): 93-115.

Holbeck, B. 1987. Interpretation of fairy tales. Danish folklore in a European perspective. Helsinki: Suomalainen Tiedeakatemia Academia Scientiarum Fennica. 
Holt, D. and D. Cameron. 2010. Cultural strategy. London: Oxford University Press.

Janov, A. 2007. Primal healing. Franklin Lakes, NJ: Career Press.

Jaszczyk, A. and B. Kochaniak. 2006. Czarodziejski pyłek, czyli metafora i bajka we wspomaganiu rozwoju małego dziecka. Kraków: Impuls.

Jenks, C. 2008. Socjologiczne konstrukty dzieciństwa. In Wprowadzenie do badań nad dzieciństwem. Edited by M.J. Kehily, 111-134. Kraków: Wydawnictwo WAM.

Jung, C.G. 1921. Psychological types. The collected works of CG Jung. Volume 6. Edited and translated by R.F.C Hull and G. Adler, 408-486. Princeton: Princeton University Press.

Jung, C.G. 1947. On the nature of the psyche. London: Ark Paperbacks.

Jung, C.G. 1948. The phenomenology of the spirit in fairy tales. The archetypes and the collective unconscious. Volume 9 (Part 1), 207-254.

Jung, C.G. 1956. Symbols and transformation. Collected works. London: Routledge and Kegan Paul.

Keating, A.L. 1995. Interrogating 'whiteness', (de)constructing 'race'. College English 57(8): 901-918.

King, P.M. and K.S. Kitchener. 1994. Developing reflective judgment. San Francisco: Jossey-Bass.

Kipper, D.A. 1997. Classical and contemporary psychodrama: A multifaceted action oriented psychotherapy. International Journal of Action Methods 50(3): 99-107.

Kozłowska, A. 2007. Zaczarowane bajki, które lecza dla dzieci $i$ dorostych. Warszawa: Wydawnictwo Akademickie ŻAK.

Le Bon, G. 1947 (1895). The crowd: A study of the popular mind. Translated by D.S. Snedders. London: Ernest Benn.

Lefrancois, G.R. 2006. Theories of human learning. Belmont, CA: Thomson Higher Education.

Le Goff, J. 1997. Świat średniowiecznej wyobraźni. Warszawa: Dom Wydawniczy Bellona.

Levi-Strauss, C. 1966. The savage mind. Chicago: The University of Chicago Press.

Levi-Strauss, C. 1969. Totemism. Harmondsworth: Penguin.

Lumsden, K. and H.M. Morgan. 2012. 'Fraping', 'sexting', 'trolling' and 'rinsing': Social networking, feminist thought and the construction of young women as victims or villains. In Proceedings of Forthcoming Feminisms: Gender Activism, Politics and Theory (BSA Gender Study Group Conference), 26 October 2012, Leeds, UK.

Lundgren, M. and L.B. Norrby. 1988. Eventyrets helbrende kraft. Copenhagen: Hans Reitzels.

Mahoney, M.R. 1997. The social construction of whiteness. In Critical white studies: Looking behind the mirror. Edited by R. Delgado and J. Stafancic. Philadelphia: Temple University Press.

Mantilla, K. 2015. Gendertrolling: How misogyny went viral. California: Praeger.

Masłowska, B. 1993. Archetypy w kulturze. Dziecko w krainie baśni. Albo-albo. Inspiracje Jungowskie 1: 87-95.

Matsumoto D. and L. Juang. 2007. Culture and psychology. Wadsworth: Belmont.

Mauss, M. 1922. The gift: Forms and functions of exchange in archaic societies. London: Routledge.

McGowen, D. 1994. What is wrong with Jung? Buffalo: Prometheus Books. 
McLaren, P. 1989. Life in schools: An introduction to critical pedagogy in the foundations of education. New York: Longman.

Mead M. 1932. An investigation of the thought of primitive children, with special reference to animism. Journal of the Royal Anthropological Institute of Great Britain and Ireland 62: 173-190.

Molicka, M. 1999. Bajki terapeutyczne. Media Rodzina: Poznań. Molicka, M. 2002. Bajkoterapia. O lękach dzieci i nowej metodzie terapii. Poznań: Media Rodzina. Molicka, M. 2003. Bajki terapeutyczne, part II. Poznań: Media Rodzina.

Moreno, J.L. 1946. Psychodrama. Volume 1. Beacon, NY: Beacon House.

Morrow, R. 2009. Norbert Elias and figurational sociology: The comeback of the century. Contemporary Sociology 38(3): 215-219.

Nichols, M.P. 1974. Outcome of brief cathartic psychotherapy. Journal of Consulting and Clinical Psychology 42(3): 403-410.

Nielsen, J. 1986. Bevidstheden og det som er helt anderledes. Copenhagen: Copenhagen Universitet Psychologisl Laboratorium.

Odrowaz-Coates, A. 2015. Is gender neutrality a post-human phenomenon? The concept of 'gender neutral' in Swedish education. Journal of Gender and Power 3(1): 113-133.

O'Farrell, C. 2005. Michel Foucault. London: Sage.

Parsons, T. 1952. The social system. London: Tavistock.

Piaget, J. 1955. La rappresentazione del mondo nel fanciullo. Torino: Einaudi.

Ponzetti, J. 2003. International encyclopaedia of marriage and family. New York: Macmillan.

Pospiszyl, K. 2013. Dramaty rodzinne $w$ mitach $i$ opowieściach. Warszawa: Wydawnictwo Akademickie Żak.

Rabinow, P. 1991. The Foucault reader: An introduction to Foucault's thought. London: Penguin.

Reed, T. 2009. Demon-lovers and their victims in British fiction. Lexington: The University Press of Kentucky.

Said, E.W. 1978. Orientalism. New York: Pantheon.

Schaffer, R. 1996. Social development. Oxford: Blackwell.

Scheff, T.J. 2001. Catharsis in healing, ritual, and drama. Lincoln, NE: iUniverse.

Schultz, D.P. and S.E. Schultz. 2004. A history of modern psychology. Belmont, CA: Wadsworth/ Thompson.

Segall, M.H., P.R. Dasen, J.W. Berry and Y.H. Poortinga. 1990. Human behavior in global perspective: An introduction to cross-cultural psychology. New York: Pergamon.

Shelburne, W.A. 1988. Mythos and logos in the thought of Carl Jung: The theory of the collective unconscious in scientific perspective. Albany: Suny Press.

Simmel, G. 1972. On individuality and social forms. Chicago: University of Chicago Press.

Simmel, G. 1950. The sociology of Georg Simmel. Glencoe: Free Press.

Smelik, A. and N. Lykke. 2008. Bits of life: Feminism at the intersections of media, bioscience, and technology. Seattle: University of Washington Press.

Smith, E. and C. Vallerga. 2006. The Scottish storyline method. Oregon: Thompson Elementary School. 
Sułek, H., M. Król and G. Krupiński. 2003. Praktyczny słownik terminów literackich. Kraków: Zielona Sowa.

Sutton, N. 1995. Bruno Bettelheim: The other side of madness. Duckworth Press: London.

Szajnberg, N.M. 1992. Educating the emotions: Bruno Bettelheim and psychoanalytic development. New York: Plenum Press.

Ungeheuer-Gołąb, A. 2012. Literackie inspiracje $w$ rozwoju przedszkolaka. Warszawa Wydawnictwo: Stowarzyszenia Bibliotekarzy Polskich.

Wais, J. 2007. Rodzina w baśniach. Albo-albo. Problemy psychologii i kultury 1: 81-89

Waksmund, R. 1986. Literatura pokoju dziecinnego. Warszawa Nasza Księgarnia.

Wasilewska, A. 2012. Fantastyka baśniowa a dziecko-wychowanie czy manipulacja? Gdańsk: Wydawnictwo Uniwersytetu Gdańskiego.

Weber, M. 1953. Class, status, party. In Class, status and power. A reader in social stratification. Edited by R. Bendix and S.M. Lipset. Glencoe: Free Press.

Weiten, W. 1992. Psychology: Themes and variations. $7^{\text {th }}$ edition. London: Brooks Cole.

Wood, K.C. 2008. Piaget's stages. Retrieved from: http://projects.coe.uga.edu/eplt/index. php?title=Piaget\%27s_Stages\#Educational_Implications (accessed 16 February 2016).

Vygotsky, L.S. 1978. Mind in society: The development of higher psychological processes. Cambridge, MA: Harvard University Press.

Zipes, J. 1979. Breaking the magic spell: Radical theories of folk and fairy tales. Austin: University of Texas Press. 